\title{
Geochemical and mineralogical characterization of a section through the nickeliferous laterite in Fazenda da Roseta, Liberdade, Minas Gerais, Brazil Caracterização geoquímica e mineralógica de uma seção ao longo da laterita niquelifera da Fazenda da Roseta, Liberdade, Minas Gerais
}

\author{
Gabriel Aragão Rodrigues Soares ${ }^{1}$, Nely Palermo², Fernando Roberto Mendes Pires² \\ 'Empresa Brasileira de Agregados Minerais S.A. - Rua da Assembleia, 10, Sala 3611, Centro, CEP 20011-901, \\ Rio de Janeiro, RJ, BR (gabriel7soares@gmail.com) \\ ${ }^{2}$ Departamento de Geologia Aplicada, Faculdade de Geologia, Universidade do Estado do Rio de Janeiro - \\ Rio de Janeiro, RJ, BR (nelpalermo@gmail.com; frm_pires@yahoo.com.br)
}

Received on October 25, 2016; accepted on May 21, 2018

\begin{abstract}
Geochemical and mineralogical studies undertaken through a section of the nickeliferous laterite profile in Fazenda da Roseta, Liberdade, Southern Minas Gerais, revealed mineable grades, both in the saprolitic horizon (A-type ore) and in the oxidized one (C-type ore). The A-type ore, well defined in the innermost $1.5 \mathrm{~m}$ of the section, boasts representative grades at the order of $1.7 \mathrm{wt} . \% \mathrm{NiO}$, with amorphous garnierite-type minerals, besides chlorite and likely serpentine, as the Ni-rich phases. An approximately $2 \mathrm{~m}$-long interval defines a transitional zone from the silicatic toward the oxidized ore, marked by the outward gradual absorption of residual blocks from the parent rock within a goethitic plasma. Impregnations and stockwork-like veins of asbolane, confirmed by local $\mathrm{Mn}$ and $\mathrm{Co}$ anomalies, delineate the outer edge of this zone. The oxidized ore stretches, based on Ni contents, for roughly $4 \mathrm{~m}$. Average grades lie about $1.2 \mathrm{wt} . \% \mathrm{NiO}$, containing goethite as the main Ni ore mineral, plus some secondary talc. Ever since the innermost part of the section, Ni has been continuously washed away, in such a manner that its concentrations become rather low in the outermost part. Anomalous geochemical signatures may indicate the occurrence of dykes of uncommon igneous rocks crosscutting the profile. The absence of smectites in the profile points out that free flow conditions have prevailed, which is reinforced by the substitution of kaolinite by gibbsite, which highlights severe hydrolysis conditions (tendency to alitization). Kaolinite veins in the gibbsite-only zone suggest post-lateritic origin. The laterite development determines an evolution in $\mathrm{pH}$ conditions from slightly alkaline in the early stages (quartz-kaolinite-zeolite association) to mildly acidic in the more advanced phases (presence of Al-goethites).
\end{abstract}

Keywords: Laterite profile; Nickeliferous; A-type ore; C-type ore; Garnierite; Goethite.

\begin{abstract}
Resumo
Estudos geoquímicos e mineralógicos empreendidos ao longo de uma seção do perfil laterítico niquelífero da Fazenda da Roseta, Liberdade, Sul de Minas Gerais, revelaram teores significativos tanto na zona saprolítica (minério tipo A) quanto no horizonte oxidado (minério tipo C). O minério tipo A, bem definido no 1,5 m inferior da seção, contém teores da ordem de 1,7 wt.\% $\mathrm{NiO}$, com minerais garnieríticos amorfos, além de clorita e provavelmente serpentina, como fases niquelíferas. Um intervalo de cerca de $2 \mathrm{~m}$ define uma zona transicional do minério silicático para o oxidado, caracterizado por gradual absorção de blocos residuais da rocha parental em um plasma goetítico. Impregnações e veios de asbolano em stockwork, em consonância com anomalias de Mn e Co, delineiam o limite externo dessa zona. Baseado no conteúdo em Ni, o minério oxidado estende-se por aproximadamente $4 \mathrm{~m}$. Teores médios giram em torno de 1,2 wt.\% NiO, em que goetita é o principal hospedeiro de Ni, além de talco secundário. Desde a porção mais interna da seção, observa-se que o Ni é continuamente lixiviado. Assinaturas geoquímicas anômalas podem indicar a ocorrência de diques de rochas exóticas cortando o regolito. A ausência de esmectitas demonstra que condições de fluxo hídrico ativas prevaleceram durante o desenvolvimento do perfil, fato corroborado pela substituição de caolinita por gibsita, implicando condições de hidrólise severas. Veios de caolinita na zona de gibsita sugerem origem pós-laterítica. A gênese do perfil define uma evolução em pH de levemente alcalino nos estágios iniciais (associação quartzo-caolinita-zeólita) para ligeiramente ácido nas fases mais avançadas (presença de goetita aluminosa).
\end{abstract}

Palavras-chave: Perfil laterítico; Niquelífero; Minério tipo A; Minério tipo C; Minerais garnieríticos; Goetita. 


\section{INTRODUCTION}

Laterites are the products of intense and/or long-lasting chemical weathering acting upon geological materials exposed to surface conditions. Such weathering profiles are well developed under hot, humid climate conditions, in regions witnessing lingering tectonic stability and low erosion rates (Brand et al., 1998; Toledo et al., 2009). The crescent intensity of oxidation, hydration and hydrolysis conditions towards the surface is directly in charge of the recognition of a series of levels with diferent sets of minerals and textures (Anand and Paine, 2002). The genesis of laterite profiles is not a static phenomenon. Instead, they are products of dynamic processes that take place over a long period of time, whereby the various horizons thicken as the alteration fronts reach increasingly deeper levels (McFarlane, 1976; Melfi and Carvalho, 1983).

Most of the current nickel (Ni) production derives from magmatic sulfide deposits, with two of the largest being the impact-related Sudbury Igneous Complex, Canada, and the flood basalt-related Norilsk-Talnak district, Russia (Naldrett, 2010). Nevertheless, most of the total Ni endowment at the earth surface is enclosed within the crystal lattice of the main rock-forming minerals in ultramafic rocks, whose grades seldom exceed 0.3 wt. $\%$ (Oliveira et al., 1992; Oliveira, 1990). In this respect, supergene processes come into play to reconcentrate certain elements (e.g., $\mathrm{Ni}, \mathrm{Co}$, $\mathrm{Al}, \mathrm{Mn}$ etc) to economically feasible grades. For instance, Ni may undergo up to a ten-fold enrichment, mirroring or even overstepping the grades found in the sulfide deposits (Brand et al., 1998; Ridley, 2013). According to Butt and Cluzel (2013), laterites constitute 60 to $70 \%$ of the world Ni resources.

In this paper, the authors present chemical and mineralogical data of the Ni-rich lateritic profile developed over an ultramafic body located at the municipality of Liberdade, state of Minas Gerais, Southeastern Brazil. Coupled with field descriptions, these data are expected to help the understanding of the supergene behavior of a wide range of elements (in particular, $\mathrm{Ni}$ ) in laterites, and lastly, the physicochemical conditions that have driven the genesis of the referred profile.

\section{NI LATERITES: CLASSIFICATION AND MAIN FEATURES}

Ni-rich laterites are residual products of chemical weathering over ultramafic rocks, meaning that the attainment of ore grades is due to progressive removal of more soluble elements (Ridley, 2013). This author highlights that, except for carbonates, ultramafic rocks hold the highest proportion of soluble components $\left(\mathrm{MgO}, \mathrm{CaO}, \mathrm{SiO}_{2}\right.$ etc) in lateritic environments. As a result, up to $90 \%$ of the original rock mass is prone to be readily dissolved. $\mathrm{Ni}$, on the other hand, presents low mobility under surficial conditions, thereby undergoing residual enrichment.

In spite of the above mentioned, the supergene behavior of Ni is not straightforward. For instance, Golightly (1981) noticed that its distribution pattern with depth cannot be explained merely by residual enrichment via leaching of soluble cations. Rather, the maximum Ni concentrations are found in the saprolite, where hydrous $\mathrm{Mg}$ minerals are still stable. This fact implies a downward Ni migration from the upper levels of the weathering profile. The upgrade in $\mathrm{Ni}$ solubility from the base to the top of the profile is clearly accompanied by changes in the geochemical environment of alteration, i.e., $\mathrm{pH}$ grades from slightly alkaline at the base to frankly acidic at top. For that reason, the acidification is entitled as the root cause for the unique behavior that $\mathrm{Ni}$ depicts (Golightly, 1981). Butt and Cluzel (2013) ascribed the term absolute accumulation to distinguish this sort of enrichment from the residual one.

Based on the main Ni-host minerals, Ni laterite deposits can be classified as (Brand et al., 1998) (Figure 1):

- Hydrous Mg silicate (A) type: also referred to as garnierite type, this category denotes a mineralization that occurs relatively deep in the regolith, more precisely, in the lower saprolite. Ni is hosted by serpentines, talc, chlorites, or an intimate mixture (garnierite) of those minerals or their non-crystalline varieties. Compositionally, A-type ore is distinguished by its low Si:Mg ratio (2-4), $\mathrm{Fe}<20 \mathrm{wt} . \%$ and mildly alkaline $\mathrm{pH}$. Average ore grade is $1.53 \mathrm{wt} . \% \mathrm{NiO}$;

- Clay (B) type: also referred to as smectitic ore, this type is characterized by the close association of $\mathrm{Ni}$ with secondary clay minerals, such as nontronite and saponite. The mineralization occurs from the intermediate to the upper levels of the saprolite, being geochemically distincted by higher $\mathrm{Si}: \mathrm{Mg}$ ratio (up to 10), $\mathrm{Fe}<30 \mathrm{wt} . \%$ and similar $\mathrm{pH}$ range to A-type ores. Average ore grade is $1.21 \mathrm{wt} . \% \mathrm{NiO}$;

- Oxide (C) type: also referred to as goethitic ore, it is assigned to the upper levels of the profile, where $\mathrm{Ni}$ is hosted in $\mathrm{Fe}$ oxi-hydroxides (goethite and amorphous varieties) and $\mathrm{Mn}$ oxi-hydroxides (e.g., asbolane). $\mathrm{Mg}$ is virtually absent, $\mathrm{Fe}$ concentration is over $40 \mathrm{wt} . \%$ and $\mathrm{pH}$ is slightly acidic. Average ore grade is $1.03 \mathrm{wt} . \% \mathrm{NiO}$.

Most Ni laterite profiles have two ore types, an oxide component and either a hydrous silicate or a clay silicate component (Brand et al., 1998; Berger et al., 2011). According to Butt and Cluzel (2013), the richest deposits formed where oxide-rich regoliths were uplifted and $\mathrm{Ni}$ leached downwards to concentrate in neoformed silicates in the saprolite (absolute accumulation). 
The characteristics of a nickeliferous laterite are highly dependent on the combined influences of climate, geomorphology, drainage, lithology and structure (Brand et al., 1998).

The vast majority of those profiles are generated under tropical climates, either humid (equatorial) or seasonally humid (savanna) (Brand et al., 1998). The deposits of Vermelho (Carajás, Pará) and Niquelândia (Goiás) are Brazilian examples of deposits formed under those conditions, respectively (Oliveira et al., 1992; Oliveira, 1990). Some deposits, however, were formed in temperate - e.g., Nickel Mountain, Oregon, USA(Marsh and Anderson, 2011) - , mediterranean - e.g., Bitincke, Albania (Thorne et al., 2012) — and tropical semi-arid — e.g., Murrin Murrin, Western Australia (Gaudin et al., 2005) - regions. The profiles of Western Australia are of relevant interest in virtue of their relatively great thickness, suggesting that more humid conditions prevailed in the past (Brand et al., 1998).
One of the known conditions for the nucleation of smectites is the alteration of serpentines under semi-arid climates (Silva and Oliveira, 1995). In this respect, B-type ores are clustered in less humid areas. In contrast, A-type ores are more abundant in more humid environments, whereas $\mathrm{C}$-type ores are widely distributed and may develop above either A- or B-type ores (Brand et al., 1998; Berger et al., 2011).

Tectonic regime plays a key role in the degree of preservation, distribution and even the class of nickeliferous laterites. Its importance resides in the control they exert on geomorphology, which, in turn, controls erosion and drainage rates. Development and preservation of thick laterites are favored by the maintenance of hot, humid climate conditions, tectonic stability, mature relief and high-stand water table (Brand et al., 1998). Surprisingly, though, the highest grades are found under free-flow conditions, typical of areas
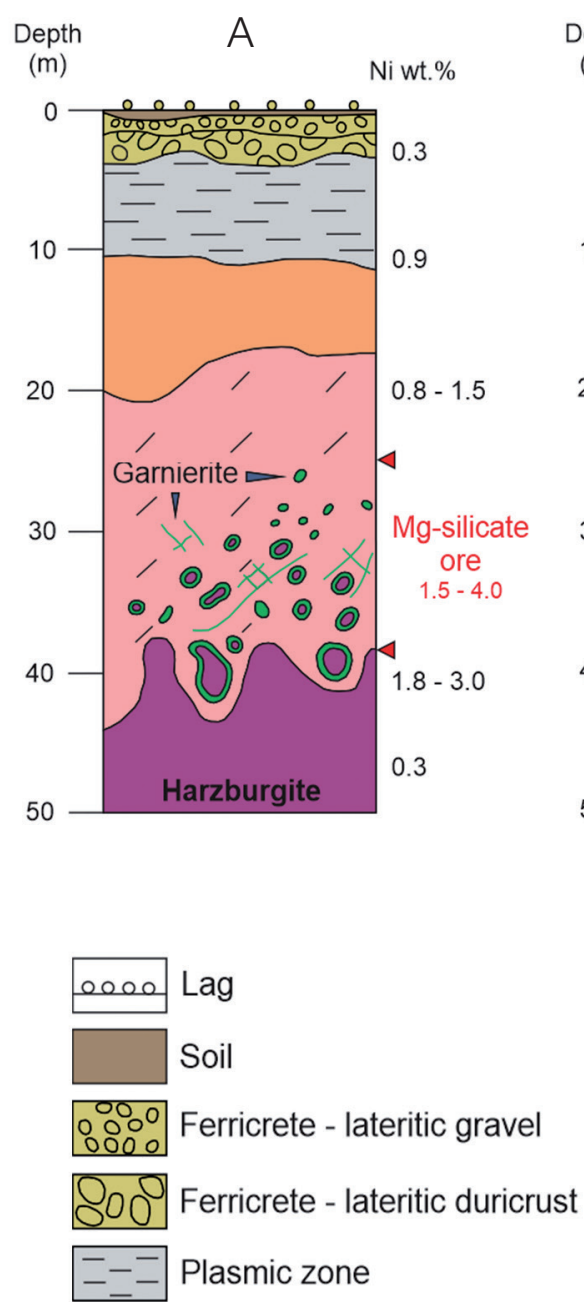
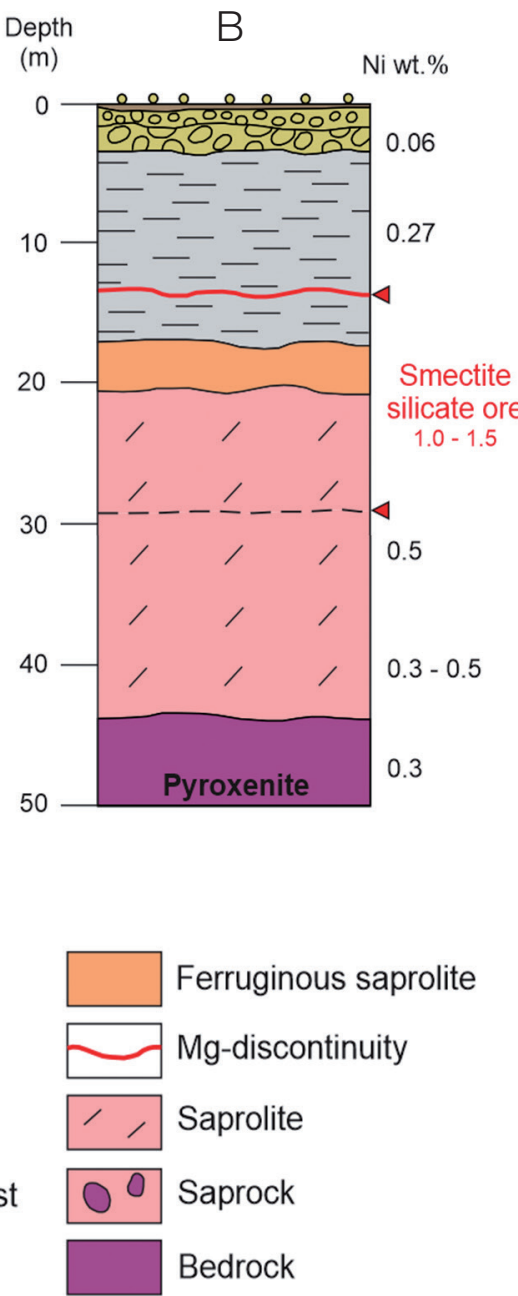

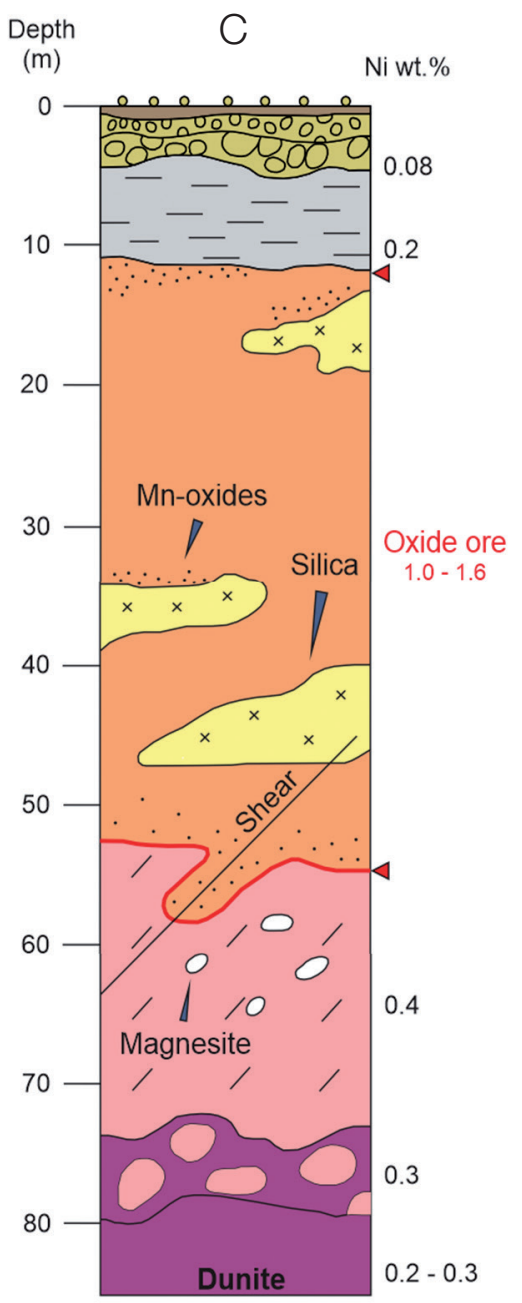

Figure 1. Lateritic profiles developed on ultramafic rocks showing the principal $\mathrm{Ni}$ laterite ores. (A) A-Type: hydrous $\mathrm{Mg}$ silicate ore; (B) B-type: clay silicate ore; (C) C-type: oxide ore. The bedrock types represent the most common lithologies associated with each profile. Based on Brand et al. (1998), Anand and Paine (2002) and Butt and Cluzel (2013). 
undergoing longstanding uplift - e.g., New Caledonia (Wells et al., 2009). Under such tectonic conditions, water table is continuously lowered as runoff is maximized. A-type ore is largely dominant in areas where those conditions prevail. The occurrence of permeable faults and drainage capture greatly enhances the precipitation of garnierite, which seems to achieve outstanding enrichment because of numerous cycles of flow and deposition (Brand et al., 1998).

The mineralogy of the parent rock is one of the most important parameters in casting the characteristics of $\mathrm{Ni}$ laterites. Silva and Oliveira (1995) outline the scenarios where smectites may arise in weathering profiles over ultramafic rocks:

- alteration of serpentines under semi-arid conditions;

- alteration of olivine under slow or impeded drainage;

- alteration of pyroxenes.

The latter boast a crystallographic compatibility with smectites during incongruent dissolution. The very same process acting upon olivine produces preferentially amorphous silica and Fe-oxy-hydroxides (Eggleton, 1986 apud Colin et al., 1990). This explains the common presence of C-type ores over dunitic rocks - e.g., Vermelho, Pará (Silva and Oliveira, 1995); Cawse, Western Australia (Brand et al., 1998).

The secondary minerals that precipitate upon congruent dissolution depend on the kinematic conditions of flow under the surface. Despite the fact that pyroxenes have a tendency to form smectites, if rapid flow conditions prevail, pyroxenederived solutions may precipitate garnierites (Brand et al., 1998). On the contrary, solutions derived from hydrolysis of olivine will only precipitate $2: 1$ clay minerals if underground flow is slow or impeded (Silva and Oliveira, 1995). The case is analogous for serpentine, from which nucleation of smectites is often seen in dryer areas (e.g., São João do Piauí, Trescases et al., 1986). In case of free-flow conditions, and hence more dilluted solutions, serpentine alters directly to kaolinite and goethite (Colin et al., 1990).

The degree of serpentinization of peridotites influences the nature and abundance of hydrous $\mathrm{Mg}$ silicates that form in profiles developed in free-draining environments (Golightly, 1979). Primary serpentine is more stable than anhydrous minerals (olivines and pyroxenes) under surface conditions, such that its stability field overlaps that of garnieritic mixtures. Therefore, fully serpentinized rocks generally produce garnierite-free profiles - e.g., Murrin Murrin, Western Australia (Gaudin et al., 2005). A peculiar example is the deposit of Angiquinho, Niquelândia, formed above a combination of dunites and pyroxenites displaying varied degrees of serpentinization. The bottom of the profile is cut by a dense network of sub-horizontal fractures. Where the parent rock is wholly serpentinized, the fractures are filled with dolomite and magnesite. In contrast, where unaltered or partially serpentinized, the parent rock has given rise to garnierite (Colin et al., 1990). Butt and Cluzel (2013) argue that some degree of serpentinization is required, under freeflow conditions, to allow the development of a thick silicate zone, particularly for garnierite precipitation. Broadly speaking, above unaltered ultramafic rocks, deposits tend to be oxide-rich. On the contrary, in highly serpentinized rocks, Ni-rich altered serpentine is the main ore mineral.

Crustal-scale structures generally behave as hydromorphic barriers. Conversely, subsidiary faults and shear zones may represent channel pathways (Figure 1), allowing meteoric fluids to percolate through ultramafic rocks and mobilize Mg, Si and Ni (e.g., Cawse, Western Australia) (Brand et al., 1998).

\section{GEOLOGICAL SETTING}

The Liberdade area is located in Southern Minas Gerais, whose complex geological history of superimposing collisional events (Brasília and Ribeira) in the Neoproterozoic-Paleozoic boundary has resulted in polyphase metamorphism and deformation (Ribeiro et al., 1995; Paciullo et al., 2003). The southern segment of the Brasília Belt is defined by a system of east-verging nappes, where basement units of the São Francisco Craton are tectonically interleaved with metasedimentary units of the Andrelândia Group (Trouw et al., 1986).

The Fazenda da Roseta ultramafic body (Figure 2) lies along the contact between the Liberdade Nappe and Carvalhos Klippe. The first is a tectonic unit recording a notable upward transition from amphibolite to granulite facies metamorphism, being composed of sillimanite/kyanite-garnet gneisses, biotite gneisses and quartzites. The second, thrusting over the first, is a bowl-shaped refolded synform made up of kyanite-bearing schists and gneisses. Different-sized ultramafic bodies are scattered throughout the base of the Carvalhos Klippe, from which only two are mappable, Morro do Corisco and Fazenda da Roseta (Almeida, 2002a, 2002b; Pinheiro and Suita, 2008, 2011).

The Fazenda da Roseta ultramafic complex is composed of at least 5 lithotypes (Pinheiro and Suita, 2008, 2011): spinel harzburgite, websterite, carbonate serpentinite, pegmatoid bronzitite and garnet-clinopyroxene-hornblende gneiss with epidote. Pinheiro and Suita (2008) described the carbonate serpentinite as a greenish rock composed of relics of orthopyroxene and olivine surrounded by serpentine in a typical mesh texture. Clinopyroxene occurs as xenoblastic crystals occupying the intergranular spaces between the pseudomorphic cumulus minerals, as do carbonates and amphiboles. Opaques are disseminated through interstitial spaces, though often observed as inclusions in carbonates and amphiboles. In addition, trails of fine-grained opaques are occasionally seen. Lepidoblastic clorite is a latter phase, generated by consumption of serpentine, carbonate and opaques. 
The garnet-clinopyroxene-hornblende gneiss was interpreted by Pinheiro and Suita (2011) as a product of local rodingitization, as suggested by its high $\mathrm{Ca}$ content. The origin of these ultramafic bodies is still controversial. Based on their intimate association with deep-water metasedimentary rocks, small size, oval shape and, most importantly, their occurrence along deep thrust faults associated with basement lenses and retrograde granulites and eclogites, Pinheiro and Suita (2008) suggested an ophiolitic provenance, hence classifying them as Alpine-type associations.

\section{MATERIALS AND METHODS}

The Fazenda da Roseta ultramafic body was a target for mineral exploration in the 1950s. Taking advantage of the adits excavated on the slopes, it was possible to access the different horizons of the profile. One adit in particular, due to the almost complete exposure of the profile, was selected for sample collection and detailed mapping (Figure 3).
A total of 10 samples (numbered from EF-LIB-01 to -10) were collected from the adit wall, regularly spaced at $1.5 \mathrm{~m}$ from the innermost part of the section outwards (Figure 4). Half the samples were processed at the Center for Mineral Technology (CETEM), and the other half at the Geologic Laboratory of Sample Preparation (LGPA) at Rio de Janeiro State University (UERJ). Sample preparation procedures encompassed milling, sieving, homogeneization and quartering.

Mineral analyses have been carried out via X-ray powder diffraction (XRD) using a Bruker AXS D4 Endeavor equipment. The data measurement conditions were as following: radiation $\mathrm{Co} \mathrm{Ka}$, wavelength $(\lambda)$ equals to 0.179021 $\mathrm{nm}$, generator running at $40 \mathrm{kV} / 40 \mathrm{~mA}, 0.02^{\circ}$ goniometer velocity and $2 \theta$ with $1 \mathrm{~s}$ by path counting time and data collected from 4 to $105^{\circ}$, with LynxEye position sensitive detector. The qualitative interpretations of the experimental data were done by comparisons with reference patterns listed in the PDF-04 database in software Bruker AXS Topas. Relative proportions of mineral phases were calculated by the Rietveld Method.

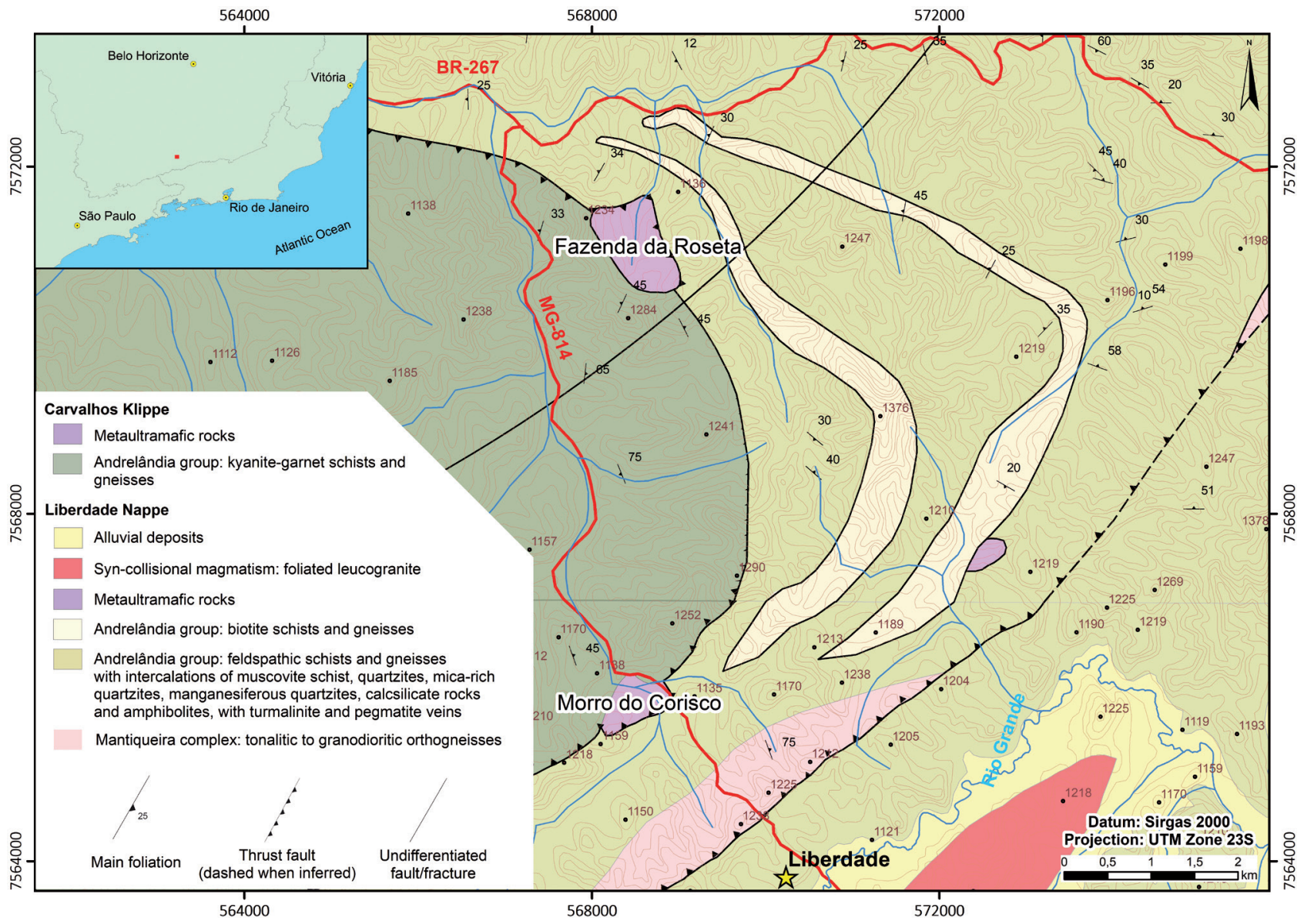

Figure 2. Geological setting of the ultramafic bodies near the city of Liberdade, MG. Compiled from the 1:100.000 scale maps of Andrelândia (Paciullo et al., 2013) and Santa Rita de Jacutinga (Heilbron et al., 2013). 
Five samples were selected for XRD analysis. In order to get meaningful and representative results, odd-numbered samples were chosen so as to have a regular data distribution. The goal for preferred selection of odd samples than even ones was to include in the dataset the innermost sample, that is, the one that most closely matches the characteristics of the parent rock.

All 10 samples, plus a replicate, were sent out to the Nomos Mineral Analysis Ltda., where Atomic Absorption (AA) analyses were carried out for elemental quantification. The diggestion method employed was a fusion with sodium carbonate and borax.

Unlike the mineralogical analysis, geochemical investigation has spanned all samples collected from the adit wall,

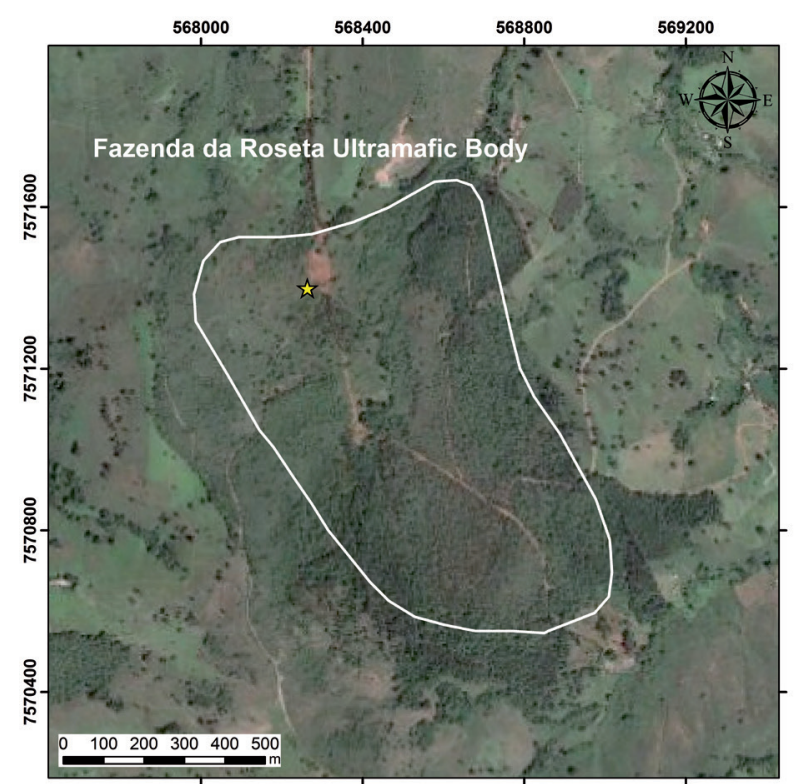

Figure 3. Location of the studied adit within the Fazenda da Roseta ultramafic body. Limits drawn according to 1:100.000 scale Andrelândia Map (Paciullo et al., 2013).

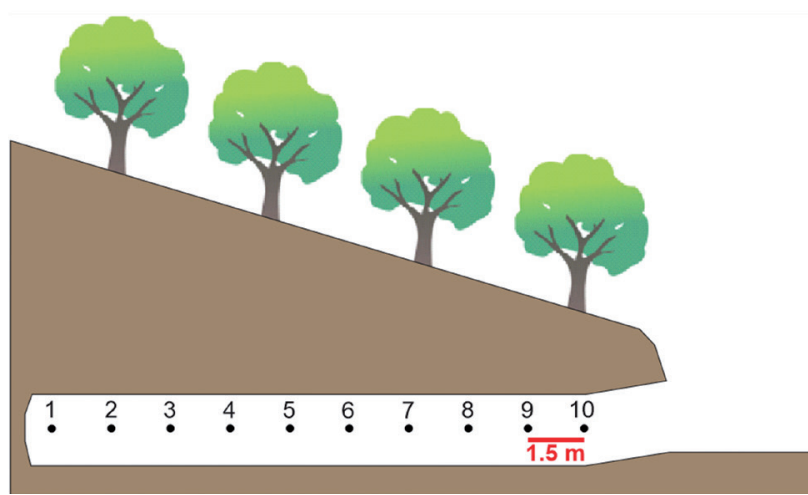

Figure 4. Schematic drawing of sample collection systematics along the adit wall. thereby prompting a denser coverage of the laterite section. As a result of closer data points, subtle aspects of the regolith evolution may then be disclosed. The geochemical analysis encompassed major and some trace elements, with emphasis on $\mathrm{Ni}$ and related elements. The combined results of field relationships, mineralogy and geochemistry are expected to provide a reasonable understanding of the supergene evolution of the ultramafic body of Fazenda da Roseta. In particular, one of the goals is to describe, at least qualitatively, the physico-chemical conditions that dictated profile development.

\section{RESULTS}

On the basis of mineralogical variations as well as changes of physical properties such as color, textures and structures, the laterite profile, as viewed from the referred adit, could be segmented into three distinctive zones. The geochemical analysis complies with the former observations and the combined data provide a more thorough understanding of the different stages of development of a laterite regolith.

\section{Saprolite}

The inner 3.5 meters of the adit correspond to the saprolitic zone of the weathering profile, where primary textures are partially preserved. This part encompasses samples 01 to 03 (Table 1). Sample 01, in particular, records the innermost part of the profile exposed in the adit. The general aspect of the altered rock is of a crumbly yellowish, finegrained mass, dominated by elongated- and planar-type minerals. Despite the advanced degree of alteration, it is evident that the radial amphibole nucleation obliterates the main rock foliation (Figure 5A). Orthopyroxene occurs as up to $2 \mathrm{~mm}$-long, typically brownish, prismatic crystals, disposed preferentially along the rock foliation. Such a plane is defined by the preferred orientation of phylossilicates (serpentine and chlorite). Kaolinite and chabazite are examples of neoformed phases. Quartz is also present. The chlorite detected in XRD analysis (Table 1) was found to be a Ni-rich component of the clinochlore-nimite series $\left[(\mathrm{Ni}, \mathrm{Mg}, \mathrm{Fe})_{5} \mathrm{Al}\left(\mathrm{Si}_{3} \mathrm{Al}\right)\left(\mathrm{O}_{10}\right)(\mathrm{OH})_{8}\right]$, of which the nickeliferous end-member nimite $\left[\left(\mathrm{Ni}_{5} \mathrm{Al}\right)\left(\mathrm{Si}_{3} \mathrm{Al}\right)\left(\mathrm{O}_{10}\right)(\mathrm{OH})_{8}\right]$ contains $17 \% \mathrm{Ni}$. Nevertheless, the mineral that draws more attention in the inner part of the section is the garnierite.

A take away fact is that 'garnierite' is a field term used by mine geologists to refer to the green Ni-rich silicate minerals that occur in many Ni laterite deposits. Actually, garnierite is a general name for the Ni-Mg hydrosilicates that usually occur as an intimate mixture that commonly includes two or more of the following minerals or their non-crystalline varieties: serpentine, talc, sepiolite and chlorite (Brindley and Maksimovic, 1974). Garnierite is broadly distributed 
in the region sampled at point 01 . It occurs as irregularly shaped, structurally controlled veins, dominantly milimetric in thickness (Figures 5B, 5C). Even though they are largely homogeneous, colloform texture is locally observed. In addition, it also shows off, though more rarely, as small nodules or clots disseminated throughout the saprolite (Figure 5D). Garnierite veins can sudden transition into poorly crystalline silica (Figure 5B).

Sample 01 , as indicated by mineralogy and its position in the profile, is the least differentiated of the dataset, that is, the one that most resembles the parent rock. Its chemical composition also signals such an observation (Table 2). Its high $\mathrm{MgO}$ content (26.75 wt.\%) complies with the ultramafic composition. Its silica content (53.87 wt.\%), on the other hand, is notably high, equivalent to those found in intermediate igneous rocks. Given the altered condition of the material, it is comprehensible to infer that such content represents a relative enrichment at the expense of more soluble components $(\mathrm{Mg}, \mathrm{Ca})$, which are more rapidly leached out of the profile. In regard to $\mathrm{Ni}$, the grade detected at sample $01(1.36 \mathrm{wt} . \% \mathrm{Ni})$ is consistent with values described in many laterite deposits.

Within the saprolite, it is possible to separate out a transitional zone from the altered rock to the outer oxide level. Represented by samples 02 and 03 , this section portrays an outward, gradual absorption of blocks of altered ultramafic rock by a reddish, oxidized material (Figure 5D). In simple words, the residual blocks, formerly joined by garnierite and silica veins, shrink and acquire amoeboid contours toward the surface, until their vanishing. The ever more dominant ferruginous material is very enriched in goethite (see Table 1). Kaolinite is distinguished as discontinuous, irregular veins partly conditioned by parent rock structures. The presence of a swarm of black-colored, discontinuous, submilimetric veins of a poorly-crystalline mineral is noticeable in the outermost part of this transitional zone (Figure 5E). This feature outlines the boundary between the saprolite and the frankly oxide zone. This very same feature follows accordingly a remarkable $\mathrm{Mg}$ dissolution front, which can also be applied to $\mathrm{Ca}$ and $\mathrm{Si}$. On the contrary, Fe and Al display exponential growth in this interval (Table 2). Sample 02, conversely, shows a very uncommon composition. Its $\mathrm{Ni}$ content is quite low ( $0.31 \mathrm{wt} . \%)$, not only for the saprolite zone, but for the profile as a whole. The same sample shows the greatest $\mathrm{Al}_{2} \mathrm{O}_{3}$ content ( $\left.32.45 \mathrm{wt} . \%\right)$, unexpected for saprolite developed over ultramafic rocks, not being inconsistent, though, if at the outermost part of the section. Furthermore, Ti, P, Zr, Y and especially Ba show unexpectedly high concentrations in this sample $(1.13,0.15 \mathrm{wt} . \%$, $148,394 \mathrm{ppm}$ and $0.59 \mathrm{wt} \%$, respectively).

In contrast with the least altered part of the section, sample 03 records the disappearance of the source-rock related mafic minerals. This residual assemblage gives place to a secondary generation of minerals, characterized by goethite, gibbsite and hematite, which will persist up to the near-surface levels of the profile. Spinel and talc were also identified. Quartz occurrence is ubiquitous all over the laterite. The zone sampled at point 03 reflects a local enrichment in $\mathrm{Mn}, \mathrm{Co}$ and $\mathrm{Cu}$. This signature indicates that the black veins in stockwork found at that point are made up of asbolane $\left[(\mathrm{Co}, \mathrm{Ni})_{1-y}\left(\mathrm{MnO}_{2}\right)_{2-}\right.$ $\left.(\mathrm{OH})_{2-2 \mathrm{y}-2 \mathrm{x}} \cdot \mathrm{nH}_{2} \mathrm{O}\right]$, a mineral commonly found at boundaries of internal zones of laterite profiles (Brand et al., 1998).

\section{Oxide zone}

From sample 03 outward, the profile is dominated by a reddish material apparently devoid of any primary structure. Since no microscopic studies were done, the distinction between a ferruginous saprolite and a plasmic zone as shown in Figure 1 could not be practiced. This stems from the fact that the only criterion of separation of such zones is the complete disappearance of inherited parent rock structures. Therefore, the authors merged them into a so-called oxide zone.

Table 1. Mineral contents in volume percent of the five samples (EF-LIB-01, -03, -05, -07 and -09) analyzed under X-ray diffraction. The figures at the bottom represent the weighted profile factor, i.e., reliability factors associated with each single analysis. Sample EF-LIB-01 records the innermost part of the adit.

\begin{tabular}{|c|c|c|c|c|c|c|c|c|c|}
\hline \multicolumn{2}{|l|}{ EF-LIB-01 } & \multicolumn{2}{|c|}{ EF-LIB-03 } & \multicolumn{2}{|c|}{ EF-LIB-05 } & \multicolumn{2}{|c|}{ EF-LIB-07 } & \multicolumn{2}{|c|}{ EF-LIB-09 } \\
\hline Mineral & Vol \% & Mineral & Vol \% & Mineral & Vol \% & Mineral & Vol \% & Mineral & Vol \% \\
\hline Tremolite & 56.2 & Goethite & 67.13 & Goethite & 42.37 & Goethite & 63.29 & Goethite & 83.84 \\
\hline Kaolinite & 12.98 & Spinel & 14.09 & Gibbsite & 24.17 & Gibbsite & 15.18 & Hematite & 11.86 \\
\hline Enstatite & 11.44 & Gibbsite & 8.91 & Spinel & 13.34 & Hematite & 12.07 & Talc & 2.24 \\
\hline Antigorite & 9.83 & Talc & 6.41 & Hematite & 6.96 & Spinel & 7.72 & Chabazite & 1.28 \\
\hline Chlorite & 3.64 & Hematite & 2.16 & Talc & 5.28 & Quartz & 1.25 & Quartz & 0.78 \\
\hline Quartz & 3.28 & Quartz & 1.3 & IImenite & 5.23 & Maghemite & 0.49 & & \\
\hline Actinolite & 2.15 & & & Quartz & 1.32 & & & & \\
\hline \multirow[t]{2}{*}{ Chabazite } & 0.5 & & & Rutile & 1.16 & & & & \\
\hline & & & & Enstatite & 0.17 & & & & \\
\hline$R w p=6.108$ & & \multicolumn{2}{|c|}{$R w p=2.162$} & Rwp $=$ & & \multicolumn{2}{|c|}{$R w p=1.998$} & \multicolumn{2}{|c|}{$R w p=1.730$} \\
\hline
\end{tabular}



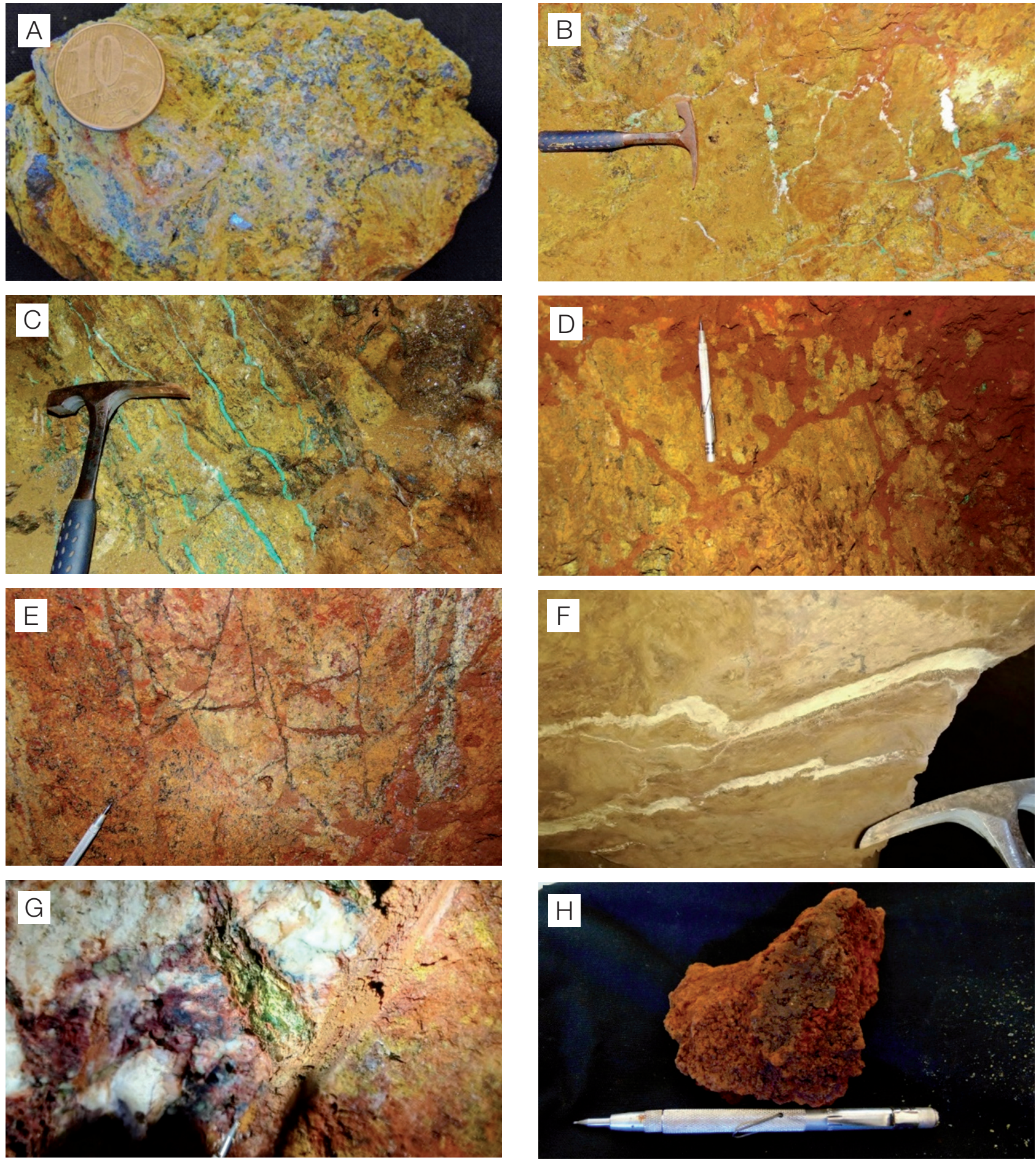

Figure 5. Nickeliferous laterite profile at Fazenda da Roseta. All photographs were taken from materials exposed at the adit studied, except E), which comes from another one within the same profile. Legend: A) deeply altered rock sampled at point 01 - notice the radially grown amphiboles (mainly tremolite) at the bottom right corner; B) composite veins of garnierite, amorphous silica and poorly-crystalline ferruginous material enclosing residual blocks of extensively altered ultramafic rock; C) structurally controlled garnierite veins cutting through the saprolite; D) amoeboid-like residual blocks of parent rocks engulfed by a goethite-rich plasma - notice the garnierite boxworks within the reddish matrix; E) stockwork-like veins of black-colored, amorphous material (likely asbolane) at the boundary between the saprolite and the oxide zone; F) shallow-dipping kaolinite veins cutting the region where gibbsite is the only secondary Al-mineral (oxide zone); G) talc venule penetrating a silica pocket at the uppermost part of the saprolite zone; $\mathrm{H}$ ) pisolith or iron concretion found at the outermost part of the profile. 
Comprising the interval from samples 03 to 09 , this zone is characterized by a homogeneous mass of mostly goethite and gibbsite (see Table 1). Besides, spinel and hematite become important phases, as well as talc. In the inner 3 meters, the occurrence of sub-horizontal kaolinite veins is relatively common (Figure $5 \mathrm{~F}$ ), more continuous and thicker than those at the saprolite zone.

In sample 05, the presence of significant proportions of ilmenite and rutile was detected, absent in the other samples. Furthermore, diminute amounts of maghemite, a cubic polymorph of hematite, were recorded in sample 07 . A striking feature is the occurrence of talc at a level where $\mathrm{Mg}$ has been largely wiped out (Figure 5G). Dismissing the negligible amounts of pyroxene in sample 05 , talc is the only $\mathrm{Mg}$ silicate in the most evolved part of the regolith.
In this part of the profile, mobile elements are virtually absent. $\mathrm{Fe}$ and $\mathrm{Al}$ are, by far, the dominant components, making up more than $80 \%$ of the regolith mass on hydrous basis and even higher if $\mathrm{H}_{2} \mathrm{O}$ is dismissed. Ni contents are low, but in samples 04 and 06 they might still be of economic interest (0.9-1.0 wt.\% Ni). Alike the saprolite zone, an anomalous sample stands out here. At point 05 , it was detected significantly high values for $\mathrm{Ti}(0,91 \mathrm{wt} . \%)$, twice as $\mathrm{Al}(20.80 \mathrm{wt} . \%$ $\mathrm{Al}_{2} \mathrm{O}_{3}$ ) as the immediately adjacent samples (hence, Fe depletion), $\mathrm{Ba}(0.54$ wt.\%), $\mathrm{Zr}(222 \mathrm{ppm})$ and $\mathrm{Nb}(210 \mathrm{ppm})$ peaks, and a negative Ni anomaly ( 0.57 wt.\%). Such geochemical signature matches that described for sample 02 . In addition, sample 06 is also of interest in the sense that it shows high $\mathrm{Mn}(0.97$ wt.\%) and $\mathrm{Cu}$ (559 ppm) values, but most importantly for its great $\mathrm{P}(0.21 \mathrm{wt} . \%)$ content.

Table 2. Chemical composition (in weight percent of oxides) of the 10 samples collected along the adit wall.

\begin{tabular}{|c|c|c|c|c|c|c|c|}
\hline Sample & $\mathrm{SiO}_{2}$ & $\mathrm{TiO}_{2}$ & $\mathrm{Al}_{2} \mathrm{O}_{3}$ & $\mathrm{Fe}_{2} \mathrm{O}_{3}$ & $\mathrm{MgO}$ & $\mathrm{CaO}$ & $\mathrm{H}_{2} \mathrm{O}$ (LOI) \\
\hline EF-LIB-01 & 53.87 & --- & 2.89 & 5.71 & 26.75 & 3.93 & 4.78 \\
\hline EF-LIB-02 & 23.40 & 1.88 & 32.45 & 22.43 & 8.36 & 0.69 & 7.60 \\
\hline EF-LIB-03 & 3.17 & --- & 12.46 & 70.46 & --- & --- & 10.20 \\
\hline EF-LIB-04 & 3.19 & --- & 9.16 & 73.28 & --- & --- & 12.05 \\
\hline EF-LIB-05 & 2.87 & 1.52 & 20.80 & 59.44 & --- & --- & 12.92 \\
\hline EF-LIB-06 & 2.88 & --- & 10.60 & 70.41 & --- & --- & 12.65 \\
\hline EF-LIB-07 & 2.86 & 0.60 & 17.41 & 65.82 & --- & --- & 11.63 \\
\hline EF-LIB-08 & 2.71 & --- & 10.41 & 75.13 & --- & --- & 9.84 \\
\hline EF-LIB-09 & 2.48 & --- & 7.73 & 79.37 & --- & --- & 8.61 \\
\hline \multirow[t]{2}{*}{ EF-LIB-10 } & 1.70 & --- & 28.63 & 56.35 & --- & --- & 7.63 \\
\hline & $\mathrm{P}_{2} \mathrm{O}_{5}$ & $\mathrm{NiO}$ & $\mathrm{MnO}$ & $\mathrm{Cr}_{2} \mathrm{O}_{3}$ & $\mathrm{CoO}$ & $\mathrm{V}_{2} \mathrm{O}_{5}$ & $\mathrm{CuO}$ \\
\hline EF-LIB-01 & --- & 1.73 & 0.12 & 0.08 & --- & --- & 0.01 \\
\hline EF-LIB-02 & 0.35 & 0.39 & 0.45 & 1.14 & 0.03 & --- & 0.06 \\
\hline EF-LIB-03 & --- & 1.26 & 1.74 & 0.10 & 0.15 & --- & 0.08 \\
\hline EF-LIB-04 & --- & 1.24 & 0.66 & 0.08 & 0.04 & --- & 0.03 \\
\hline EF-LIB-05 & --- & 0.73 & 0.67 & 0.10 & 0.03 & --- & 0.03 \\
\hline EF-LIB-06 & 0.49 & 1.17 & 1.25 & 0.10 & 0.04 & 0.07 & 0.07 \\
\hline EF-LIB-07 & --- & 0.70 & 0.52 & 0.10 & 0.03 & 0.04 & 0.03 \\
\hline EF-LIB-08 & --- & 0.90 & 0.47 & 0.11 & 0.03 & 0.08 & 0.02 \\
\hline EF-LIB-09 & --- & 1.01 & 0.37 & 0.06 & 0.03 & --- & 0.04 \\
\hline \multirow[t]{2}{*}{ EF-LIB-10 } & 0.24 & 0.91 & 1.55 & 2.47 & 0.15 & -- & 0.03 \\
\hline & $\mathrm{ZnO}$ & $\mathrm{SO}_{3}$ & $\mathrm{WO}_{3}$ & $\mathrm{BaO}$ & $\mathrm{Y}_{2} \mathrm{O}_{3}$ & $\mathrm{ZrO}_{2}$ & $\mathrm{Nb}_{2} \mathrm{O}_{5}$ \\
\hline EF-LIB-01 & 0.09 & --- & 0.01 & --- & 0.02 & --- & --- \\
\hline EF-LIB-02 & 0.04 & --- & --- & 0.66 & 0.05 & 0.02 & --- \\
\hline EF-LIB-03 & 0.08 & 0.31 & --- & --- & --- & --- & --- \\
\hline EF-LIB-04 & --- & 0.26 & --- & --- & --- & --- & --- \\
\hline EF-LIB-05 & 0.03 & 0.25 & --- & 0.54 & --- & 0.03 & 0.03 \\
\hline EF-LIB-06 & --- & 0.22 & --- & --- & --- & --- & --- \\
\hline EF-LIB-07 & --- & 0.28 & --- & --- & --- & --- & --- \\
\hline EF-LIB-08 & --- & 0.30 & --- & --- & --- & --- & --- \\
\hline EF-LIB-09 & --- & 0.30 & --- & --- & --- & --- & --- \\
\hline EF-LIB-10 & --- & 0.35 & & & & & \\
\hline
\end{tabular}




\section{Ferricrete}

The hardening of regolith is noticeable from the part of the section sampled at point 09 up to the terrane surface, highlighting the apical zone of ferricrete or laterite residue (Figure 5H). Talc was also detected at this zone. Fe oxi-hydroxides account for $95 \%$ of the modal composition of sample 09, which marks the disappearance of gibbsite (Table 1).

In regard to the geochemical signature, this zone represents the most evolved portion of the studied section, i.e., the most enriched in immobile elements. Notwithstanding, samples 09 and 10 show remarkable diferences. The first is the Fe-richest sample throughout the section $(79.37 \%$ $\mathrm{Fe}_{2} \mathrm{O}_{3}$ ), in addition to displaying very low contents for $\mathrm{Mn}$ and $\mathrm{Cr}(0.29$ wt.\% and $411 \mathrm{ppm}$, respectively). From this sample to the next, Mn and Al undergo a roughly four-fold enrichment (1.20 wt.\% $\mathrm{Mn}$ and 28.63 wt. $\% \mathrm{Al}_{2} \mathrm{O}_{3}$ ), hence Fe drops accordingly (from 79.36 to $56.35 \mathrm{wt} . \%$ ). Co is also increased by 5 times, reaching $1,200 \mathrm{ppm}$. Nevertheless, the most outstanding enrichment is that shown by $\mathrm{Cr}$, as sample 10 boasts 40 times more $\mathrm{Cr}$ than the former one, attaining $1.7 \mathrm{wt} . \%$ on elemental basis. Furthermore, Ni grades at this zone are rather low (in the order of $0.7 \mathrm{wt} . \%$ ), and depict the final edge of a smoothly decreasing trend from sample 01 outward.

Figure 6 summarizes the interplay of field descriptions, mineral and geochemical analysis presented to date. Notice the distinct regolith zones and their principal textural elements and their relationship with mineral and geochemical transformations along the studied section.

\section{DISCUSSIONS}

Taking advantage of the availability of geochemical data from fresh rock samples of the same ultramafic body (Pinheiro and Suita, 2008), comparisons could be carried out as to shed some light not only into the genesis of the ultramafic rocks, but also into the degree of leaching that the saprolite may have been subjected to. In this comparison, a broad scope of ultramafic rocks has been accounted for. Ophiolite complexes, komatiite lavas, major layered intrusions and Alaskan-type suites are some examples used in this endeavor. The ternary diagrams of Coleman (1977) for petrotectonic classification of ultramafic rocks came to be a handy tool (Figure 7). Despite the extensive alteration, the saprolite still holds strong chemical bonds to its source rock. The analysis of Pinheiro and Suita (2008) portray an astonishing similarity of the small ultramafic bodies located at Liberdade with abyssal or metamorphic peridotites, which represent residues from mantle melting typically found at the base of ophiolite sequences.
The adit sample 01 fits in the compositional range of those peridotites in the $\mathrm{FeO}-\mathrm{Na}_{2} \mathrm{O}+\mathrm{K}_{2} \mathrm{O}-\mathrm{MgO}$ ternary diagram. On the other hand, it diverts from the field of abyssal peridotites in the diagram $\mathrm{Al}_{2} \mathrm{O}_{3}-\mathrm{CaO}-\mathrm{MgO}$. The relatively high alumina content is likely due to leaching of soluble components, given that $\mathrm{Al}$ is highly immobile. The Ca enrichment, in turn, cannot be weathering-derived once that chemical element is very mobile and amphiboles are the main mineral phases recorded. In this respect, the argument put forward by Pinheiro and Suita (2011) that those rocks have undergone intense $\mathrm{Ca}$ metasomatism, locally causing rodingitization, is seemingly comprehensive. A further take away point to extract from the plots is that the whole set of processes acting upon the source rock until the stage of saprolite, at point 01 , have not produced a noticeable Fe enrichment.

Along the extent of the segment of the laterite cover studied in this work, the highest Ni grade was found where garnierite veins are widespread. This type of mineralization falls into the A-type ore class. The distinction of colloform texture in garnierite veins indicates open space filling from a solution. Considering, thus, these veins as products of solutions derived from destruction of primary silicates, the lateral gradation from garnierite to poorly-crystalline silica represents the depletion in $\mathrm{Ni}$ and $\mathrm{Mg}$ in the percolating fluids. Nevertheless, the garnierite veins, coatings and clots might not be sufficiently abundant to give rise to such grade. In this respect, sampling at point 01 was very carefully conducted as to get a good representativity. Silva and Oliveira (1995) tracked the compositional evolution from source rock to saprolite in the Vermelho deposit, northern Brazil. These authors noticed that as primary phylossilicates (serpentines and clorites) turned from dark green to yellowish green with progressive alteration, their Ni contents increased accordingly. Therefore, the color of the same minerals in point 01 may suggest that they are likewise $\mathrm{Ni}$-bearing phases. Indeed, $\mathrm{Ni}$-rich chlorite was detected in the groundmass. Their occurrence in the garnierite mixture could not be confirmed though.

Moving further out the section, Ni concentrations are kept high even though garnierite, just like other hydrous Mg silicates, is no longer a stable phase. Such concentrations ( 0.9 to $1.0 \mathrm{wt} . \% \mathrm{Ni}$ ) are quite common in C-type ores. Indeed, the maintenance of those grades where garnierite no longer exists implies that $\mathrm{Ni}$ is hosted in the structure of goethite. The detection of talc in this part of the profile poses a question on whether it is a primary mineral or a neoformed phase. The absence of talc in the innermost part of the section may lead one to argue that its recognition is due to lateral lithological variations across a horizontal section. In fact, such idea cannot be ruled out. Conversely, its intimate association with silica pockets may indicate a secondary nature. The presence of supergene talc in weathered serpentinites 
WSW

ENE

Saprolite $\quad \mid$ Oxide Zone (Ferruginous Saprolite + Plasmic Zone) $\mid$ Ferricrete

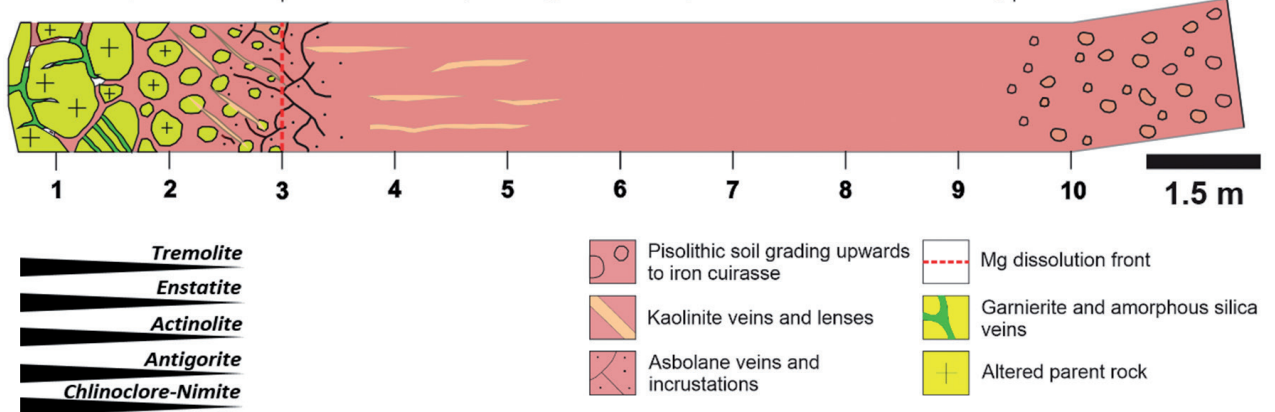

Kaolinite

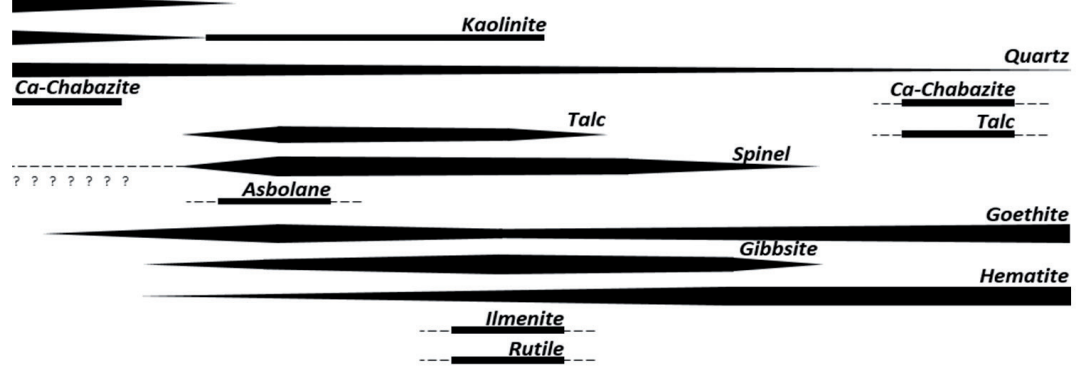

Maghemite
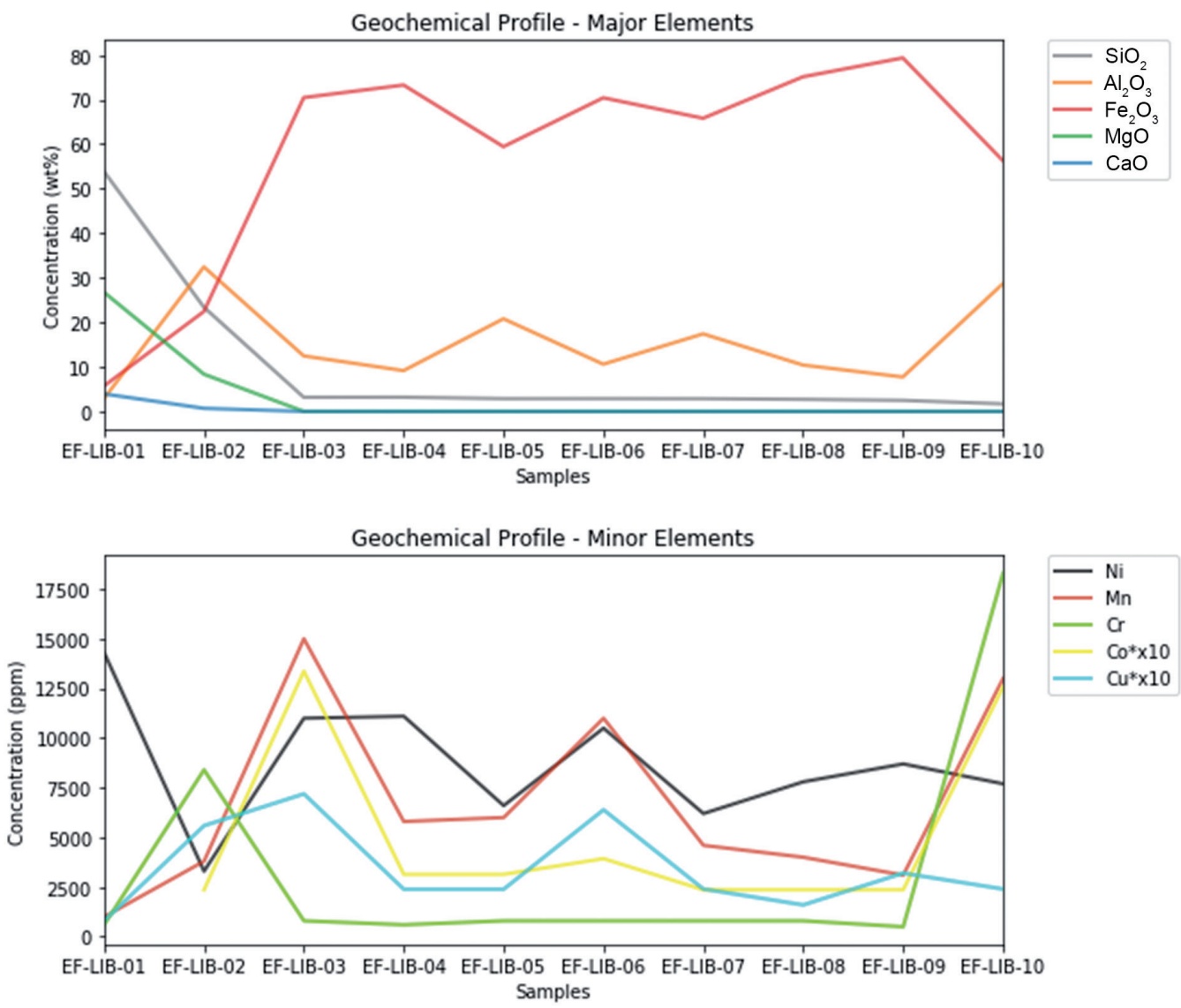

Figure 6. Mineral and geochemical transformations across the studied section. 
is discussed by Noack and Duplay (1983). According to Silva and Oliveira (1995), the talc in the oxidized zone of the Vermelho deposit is Ni-rich, which may happen in this case as well. In addition, at Vermelho, talc is also associated with silica pockets at various scales.

One of the puzzling aspects of the studied section refers to kaolinite distribution. This mineral is no longer detected in XRD from sample 03 onwards, implying that it becomes unstable at some point within the saprolite. Nonetheless, this presence is readily confirmed by local veins across a significantly broad extent of the section. In other words, there is a strong segregation between kaolinite and gibbsite through the regolith as the reddish groundmass gets kaolinite-free. Such nearly perfect segregation between kaolinite and gibbsite is a somewhat intriguing fact. Indeed, kaolinite veins take place at a level where this mineral is no longer stable, that is, a strongly $\mathrm{Si}$ depleted zone. Valeton (1972) describes irregular kaolinite veins within a nepheline syenite-derived laterite profile in Arkansas, USA. Likewise, those veins cut through a region where the stable $\mathrm{Al}$ phases are the bauxite minerals. This author also noticed that their orientation reflected the fracturing pattern of the source rock. Valeton (1972) suggested that such fracturing is post-lateritic, allowing the infiltration of silica-rich fluids until deep zones of the profile. Meanwhile, abundant kaolinite is formed, intruding the gibbsite-rich zone during subsequent ascension.

The staggering variations in metal contents between points 09 and 10 cannot be solely assigned to residual enrichment. Those changes very likely result from lateral variations in lithological facies. The local existence of rocks with higher contents in heavy minerals (spinels and sulfides), podiform chromitites for instance, suits such geochemical signature. Moreover, those chromite-rich nodules are common features in mantle-derived rocks (e.g., abyssal peridotites). Additionally, the preservation of high values of $\mathrm{Al}$ in a region where gibbsite is no longer present implies that $\mathrm{Al}$ is trapped within goethite structure.

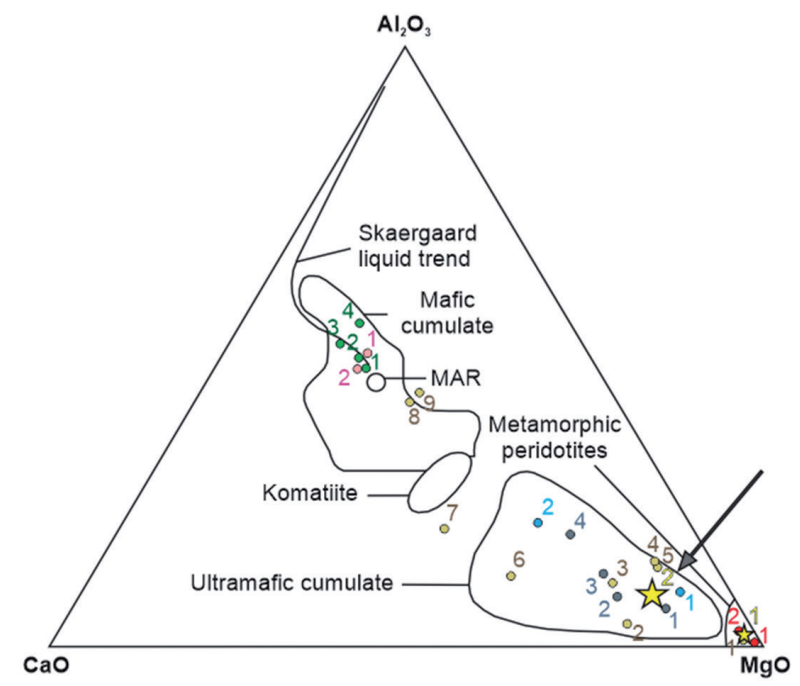

Archean tholeiites (Condie, 1976): 1 - Enriched; 2 - Depleted

Modern tholeiites (Condie, 1976): 1 - Mid Ocean Ridge Basalts (MORB); 2 - Continental Basalts; 3 - Arc Basalts; 4 - Calc-Alkaline Basalts

Alaskan-type ultramafic intrusions: 1 - Dunites from the Giant Mascot Suite, BC, Canada (Manot, 2014); 2 - Peridotites from the Giant Mascot Suite (Manor, 2014); 3 - Wehrlites from the Quetico Intrusion, ON, Canada (Pettigrew and Hattori, 2006); 4 - Peridotites from the Tuerkubantao intrusion, China (Deng et al., 2015); 5 - Peridotites from NE Turkey (Eyuboglu et al., 2010); 6 - Pyroxenites from the Giant Mascot Suite (Manor, 2014); 7 - Clinopyroxenites from the Quetico intrusion (Pettigrew and Hattori, 2006); 8 - Hornblendites from the Giant Mascot Suite (Manor, 2014); 9 - Hornblendites from the Quetico intrusion (Pettigrew and Hattori, 2006)

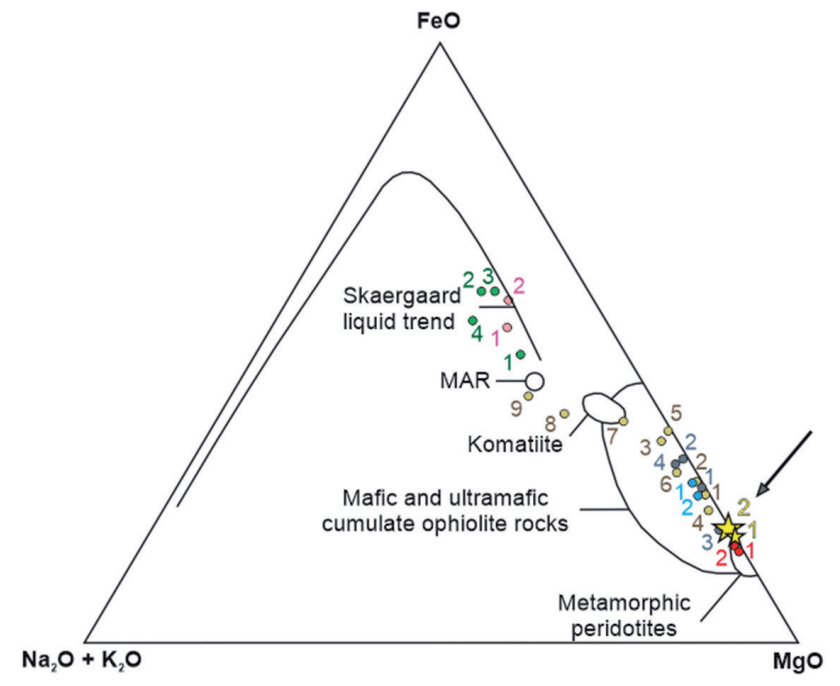

Ultramafic Cumulates: 1 - Lower Zone and Lower Critical Zone of the Bushveld Complex, South Africa (Godel et al., 2011); 2 - Basal cumulates from ophiolite sequences (Compiled by Coleman, 1977)

Greenstone Belts: 1 - Komatiites from South African Greenstone Belts (Villaume and Rose, 1977); 2 - Komatiites from the Crixás Greenstone Belt, Brazil (Arndt et al., 1989); 3 - Plutonic ultramafics from the Rio das Velhas Greenstone Belt, Brazil (Fonseca and Evangelista, 2013); 4 Komatiites from Canadian Greenstone Belts (Villaume and Rose, 1977)

Ophiolite metamorphic peridotites (Compiled by Coleman, 1977): 1 Dunites; 2 - Harzburgites

th Ultramafic rocks from the Morro do Corisco and Fazenda da Roseta: 1Sepentinites from Morro do Corisco and Fazenda da Roseta (Pinheiro and Suita, 2008); 2 - Sample EF-LIB-01 from the bottom of the adit wall studied in this work (indicated by the black arrows)

Figure 7. Coleman (1977) ternary diagrams for classification of ultramafic rocks. MAR stands for Mid Atlantic Ridge. The superimposed plots of chemical data represent a collection of ultramafic rocks from several places and tectonic settings. The arrow points to sample EF-LIB-01. The sources for the geochemical data used for comparison are indicated in the legend above. 
Overall, the evolution of the laterite profile at Fazenda da Roseta complies with the expected general trend of leaching of soluble cations and, thus, residual enrichment of less mobile elements. In particular, there is a strikingly noticeable $\mathrm{Mg}$ dissolution front. Despite the effects of lateral variations when studying horizontal sections, a couple of samples display geochemical signatures incompatible with mantle melting residues. The reason for that is the abundance in the so-called incompatible elements (Ba, Ti, P, Al, Zr, Y, Nb). In addition, those samples show off remarkably negative values for $\mathrm{Ni}$, representing outliers in its overall evolution. Ba, for instance, is one of the elements with the highest solubility in aqueous solutions (Large Ion Lithophile Element), not being expected, thus, to be detected in weathering profiles, especially in large amounts (over 0.5 wt.\%). Bearing in mind that $\mathrm{Ba}$ is extremely mobile, such amount reveals that its source rock is even more enriched in this element. The abovementioned geochemical footprint depicts an alkaline rock of uncommon composition. Zozulya et al. (2010) found out ultrapotassic dykes (lamproites) in northern Norway with extremely similar chemical composition. Their mineral assemblage comprises phlogopite, arfvedsonite, orthoclase, apatite, baotite, rutile, zircon, quartz, barite, Ti-aegerine and $\mathrm{Na}-\mathrm{Mg}$-Ba phosphates. A starking point is that $\mathrm{Ti}$ anomalies were also encountered in the pelitic schists and gneisses of the Carvalhos Klippe and Liberdade Nappe (results of mineral exploration). This fact points out that the source of this anomaly is neither the ultramafics nor the metapelites, and that its source rock is affecting both indiscriminately. Therefore, the Norwegian dykes may find analogous in the studied area.

\section{THE SUPERGENE ENVIRONMENT AT FAZENDA DA ROSETA}

The geochemical and mineralogical evolution of a laterite profile provides valuable insights into the prevailing physicochemical conditions of the supergene environment.

The $\mathrm{pH}$ of percolating waters has a profound effect on mineral stability. Taylor and Eggleton (2001) advance that, under frankly alkaline conditions, magnesite or sepiolite precipitate and quartz is dissolved. On the contrary, kaolinite gives place to alunite under very acidic conditions. Therefore, the coexistence of quartz and kaolinite at the inner part of the studied section implies nonextreme $\mathrm{pH}$ conditions. The velocity whereby water flows through regolith profile also plays a fundamental role in mineral stability. Where flow is slow or impeded, water is afforded a longer residence time within the profile and, consequently, is warranted more time to react with minerals and attain chemical equilibrium. As a result, water may saturate in almost all elements being released from minerals, thereby precipitating smectites (Taylor and Eggleton, 2001). Nonetheless, the assemblage of secondary minerals at Fazenda da Roseta (kaolinite, gibbsite, goethite, hematite, quartz) points out that saturation was only reached for $\mathrm{Fe}, \mathrm{Al}$ and $\mathrm{Si}$. In fact, kaolinite is prematurely replaced by gibbsite at the profile base, which reveals that weathering solutions were so dilluted that prevented even Si to attain saturation. Mobile elements were readily washed away.

$\mathrm{Al}$ content in goethite is also a qualitative $\mathrm{pH}$ index. A free-draining regolith is normally more acidic than one with stagnant conditions of flow. Acidic waters are more efficient in dissolving $\mathrm{Al}$ so that goethite precipitated from Al-rich fluids will incorporate much of this element (Taylor and Egleton, 2001). Comparing chemical data and mineral abundances, approximate calculations of $\mathrm{Al}$ content in goethite can be carried out. At sample 07, considering that spinel composition is $\mathrm{MgAl}_{2} \mathrm{O}_{4}$, the estimation of $\mathrm{Al}_{2} \mathrm{O}_{3}$ content in goethite is approximately $2 \mathrm{wt} . \%$. At sample 09 , this proportion rises to $9 \mathrm{wt} . \%$, hence demonstrating an acidification of goethite precipitation conditions outwards across the section.

Zeolites, typical minerals of very low-grade metamorphism, may nucleate in pedogenetic environments, but according to Ming and Boettinger (2001), its occurrence is limited to alkaline soils with high content of soluble salts. Such conditions may, at least partly, be attained at the inner saprolite. The process whereby zeolite precipitates in soil environments is named zeolitization, being classified as a type of partial alkalinolysis (Melfi and Carvalho, 1983). However, the occurrence of rather small amounts of zeolite along with quartz may reveal that $\mathrm{pH}$ conditions were just mildly alkaline, and hence not characterizing a genuine alkalinolysis. The detection of this mineral in the outermost part of the laterite profile might put in check the status quo on the stability of zeolites in supergene environments.

The lack of evidences for extreme $\mathrm{pH}$ conditions identifies normal hydrolysis, main weathering mechanism in equatorial and tropical regions (Melfi and Carvalho, 1983). The classification of hydrolisis depends on the degree of leaching of soluble cations and $\mathrm{Si}$. Particularly, in this case there are no 2:1 clay minerals, with kaolinite (1:1) being the only clay phase. The thorough removal of soluble cations and the arrangement of $\mathrm{Al}$ and $\mathrm{Si}$ to form kaolinite is regarded as monossialitization, an incomplete hydrolysis. The vanishing of kaolinite, through silica leaching, and its replacement by gibbsite highlight severe hydrolysis conditions outwards, approaching to allitization. 


\section{CONCLUSIONS}

The study of the nickeliferous laterite at Fazenda da Roseta unfolds aspects related to not only its supergene evolution, but also to the source rocks underneath.

In regard to the latter, changes in mineral contents and chemical composition across the profile section possibly indicate ultramafic rock facies variations (e.g., metal-rich lithologies). Nevertheless, the feature that stands out the most is the anomalous abundance of a set of incompatible elements in mantle rocks, which may indicate the presence of dykes of rare igneous rocks.

Based on mineralogical and textural characteristics, three well-defined zones could be identified in the section: saprolite, oxide zone and ferricrete (laterite residue). Such an evolution marks the continuous transformation and equilibration, under surface conditions, of geological materials from the primary source rock up to an iron crust. This evolution records a mineral succession where stability is steered by chemical composition. In other words, Mgand Ca-rich minerals are progressively replaced by $\mathrm{Fe}$ - and Al-rich phases as those soluble cations are leached out of the system. Ni also depicts a general decreasing trend, but due to its relatively lower solubility, the depletion curve is shallower-dipping. In that sense, it witnesses the overall mineral transformations, being shifted from hydrous $\mathrm{Mg}$ silicates at the base to Fe-Mn oxi-hydroxides at intermediate levels of the section.

The diagnostic characteristic of the laterite profile at Fazenda da Roseta is the sudden transition from a Mg-silicaterich zone (with both hypogene and neoformed minerals) to an oxidized level (extremely depleted in mobile elements) without an intermediate clayey horizon. In Brazil, this evolution is only shared by the laterites at Morro do Corisco (Esson and Santos, 1978 apud Esson, 1983; Esson, 1983) and Morro do Níquel (Oliveira et al., 1992; Oliveira 1990). Given the known conditions for smectite formation in weathering profiles over ultramafic rocks, it is reasonable to say that the evolution of this profile most closely reflected that observed in the modern accretionary terranes (e.g., New Caledonia), where rapid flow conditions promote the development of C-type ores right above garnierite-bearing zones, with little smectite. In other words, serpentines and other Mg-rich minerals alter directly to kaolinite and goethite. In fact, the most prominent feature of rapid hydrological flow through this laterite profile is the early replacement of kaolinite for gibbsite as the main $\mathrm{Al}$ phase. The observation of kaolinite veins within a gibbsite-only level might suggest a post-lateritic origin.

Very active drainage is driven, among others, by regional uplift. In this respect, much of the supergene evolution of the ultramafic bodies in Liberdade may be synchronous to the Mantiqueira Mountain Range uprise.
Further studies should open up to new exploration adits and be more focused on analysis of mineral separates in order to track chemical evolution of the mineral phases and better assess garnierite composition. In addition, it would be of interest to map the distribution of incompatible element anomalies throughout the ultramafic body and its surrounding wall rocks. Finally, one may investigate the origin and distribution of talc in the regolith and the implications for the supergene evolution.

\section{ACKNOWLEDGEMENTS}

We are grateful to Iranildo dos Reis, dweller of Liberdade, who kindly guided us through the studied area, no to mention the esteemed colleagues Caio Soares and Eduardo Socoloff for support in the field work. A special thanks to Pedro Garcia, who made possible sample preparation and X-ray diffraction. Many thanks also to Mr. Mauro Yamamoto, who gently volunteered to undertake the chemical analysis, indispensable for the main goals to be achieved.

\section{REFERENCES}

Almeida, S. (2002a). A diversidade de texturas e associações minerais de rochas ultramáficas na região sul de Minas Gerais como resultado da atuação distinta de processos metamórficos e tectônicos ao longo da Faixa Ribeira. Revista de Ciências Exatas, 21(2), 101-113.

Almeida, S. (2002b). Evolução textural-metamórfica de metawebsteritos da fazenda da roseta, Liberdade, MG. Revista de Ciências Exatas, 21(1), 21-35.

Anand, R. R., Paine, M. (2002). Regolith geology of the Yilgarn Craton, Western Australia: implications for exploration. Australian Journal of Earth Sciences, 49, 3-162. https://doi.org/10.1046/j.1440-0952.2002.00912.x

Arndt, N. T., Teixeira, N. A., White, W. M. (1989). Bizarre geochemistry of komatiites from the Crixás greenstone belt, Brazil. Contributions to Mineralogy and Petrology, 101(2), 187-197. https://doi.org/10.1007/BF00375305

Berger, V. I., Singer, D. A., Bliss, J. D., Moring, B. C. (2011). Ni-Co Laterite Deposits of the World - Database and Grade and Tonnage Models. U.S. Geological Survey Open-File report 2011-1058. $26 \mathrm{p}$.

Brand, N. W., Butt, C. R. M., Elias, M. (1998). Nickel laterites: classification and features. Journal of Australian Geology and Geophysics, 17(4), 81-88. 
Brindley, G.W., Maksimovic,Z.(1974). Thenature and nomenclature of hydrous nickel-containing silicates. Clay Minerals, 10, 271-277.

Butt, C. R. M., Cluzel, D. (2013). Nickel laterite ore deposits: weathered serpentinites. Elements, 9, 123-128. https://doi. org/10.2113/gselements.9.2.123

Coleman, R. G. (1977). Ophiolites: Ancient Oceanic Lithosphere? New York: Springer Verlag.

Colin, F., Nahon, D., Trescases, J. J., Melfi, A. J. (1990). Lateritic Weathering of Pyroxenites at Niquelandia, Goias, Brazil: The Supergene behavior of Nickel. Economic Geology, 85, 1010-1023. https://doi.org/10.2113/gsecongeo.85.5.1010

Condie, K. C. (1976). Trace-element geochemistry of Archean greenstone belts. Earth Science Reviews, 12(4), 393-417. https://doi.org/10.1016/0012-8252(76)90012-X

Deng, Y., Yuan, F., Zhou, T., Xu, C., Zhang, D., Guo, X. (2015). Geochemical characteristics and tectonic setting of the Tuerkubantao mafic-ultramafic intrusion in West Junggar, Xinjiang, China. Geoscience Frontiers, 6, 141-152. https:// doi.org/10.1016/j.gsf.2013.10.003

Esson, J. (1983). Geochemistry of the nickeliferous laterite profile, Liberdade, Brazil. In: R. C. L. Wilson (Ed.), Residual Deposits: Surface Related Weathering Processes and Raw Materials (91-99). London: Geological Society. (Geological Society of London Special Publication, 11).

Eyuboglu, Y., Dilek, Y., Bozkurt, E., Bektas, O., Rojay, B., Sen, C. (2010). Structure and geochemistry of an Alaskan-type maficultramafic complex in the Eastern Pontides, NE Turkey. Gondwana Research, 18(1), 230-252. https://doi.org/10.1016/j.gr.2010.01.008

Fonseca, G. M., Evangelista, H. J. (2013). Rochas ultramáficas plutônicas do greenstone belt Rio das Velhas na porção central do Quadrilátero Ferrífero, Minas Gerais, Brasil. Revista da Escola de Minas, 66(1), 67-75. http://dx.doi.org/10.1590/ S0370-44672013000100009

Gaudin, A., Decarreau, A., Noack, Y., Grauby, O. (2005). Clay mineralogy of the nickel laterite ore developed from serpentinised peridotites at Murrin Murrin. Western Australia. Australian Journal of Earth Sciences, 52, 231-241. https:// doi.org/10.1080/08120090500139406

Godel, B., Barnes, S. J., Maier, W. D. (2011). Parental magma composition inferred from trace element in cumulus and intercumulus silicate minerals: An example from the Lower and Lower Critical Zones of the Bushveld Complex, South Africa. Lithos, 125, 537552. http://dx.doi.org/doi:10.1016/j.lithos.2011.03.010
Golightly, J. P. (1979). Nickeliferous laterites: a general description. In: D. J. I. Evans, R. S. Shoemaker, H. Veltman (Eds.), International Laterite Symposium. New York: Society of Mining Engineers. p. 3-23.

Golightly, J. P. (1981) Nickeliferous laterite deposits. Economic Geology, $75^{\text {th }}$ Anniversary Volume, 710-735. https://doi.org/10.5382/AV75.18

Heilbron, M., Tupinambá, M., Junho, M. C. B., Ribeiro, A., Paciullo, F. V. P., Trouw, R. A. J., Valeriano, C. M., Toledo, C., Medeiros, R. M., Roig, H. L. (2013). Mapa Geológico da Folha Santa Rita de Jacutinga. Escala 1:100.000. Belo Horizonte: Companhia de Desenvolvimento Econômico de Minas Gerais.

Manor, M. J. (2014). Convergent Margin Ni-Cu-PGE Deposits: Geology, Geochronology and Geochemistry of the Giant Mascot Magmatic Sulphide Deposit, Hope, British Columbia. Dissertation (Mastering course). Vancouver: Department of Earth Ocean and Atmospheric Sciences University of British Columbia.

Marsh, E. E., Anderson, E. D. (2011). Ni-Co laterite deposits: U.S. Geological Survey Open-File Report, 2011-1259, 9 p.

McFarlane, M. J. (1976). Laterite and Landscape. London: Academic Press.

Melfi, A. J., Carvalho, A. (1983). Lateritisation Processes. São Paulo: IAG/USP.

Ming, D. W., Boettinger, J. L. (2001). Zeolites in Soil Environments. Reviews in Mineralogy and Geochemistry, 45, 323-345. https://doi.org/10.2138/rmg.2001.45.11

Naldrett, A. J. (2010). From the mantle to the bank: the life of a Ni-Cu-(PGE) sulfide deposit. South African Journal of Geology, 113, 1-32. https://doi.org/10.2113/ gssajg.113.1-1

Noack, Y., Duplay, J. (1983). Talc and the weatheringhydrothermal alteration boundary. Sciences Géologiques, Bulletins et Mémoires, 72, 121-130.

Oliveira, S. M. B. (1990). Os depósitos de níquel laterítico do Brasil. Tese (Livre Docência). São Paulo: Instituto de Geociências - Universidade de São Paulo, 89 p.

Oliveira, S. M. B., Trescases, J. J., Melfi, A. J. (1992). Lateritic nickel deposits of Brazil. Mineralium Deposita, 27, 137-146. https://doi.org/10.1007/BF00197099 
Paciullo, F. V. P., Ribeiro, A., Trouw, R. A. J. (2003). Geologia da Folha Andrelândia 1:100.000. In: A. C. Pedrosa Soares, C. M. Noce, R. A. J. Trouw, M. Heilbron (Eds.), Geologia e recursos minerais do sudeste mineiro. Projeto Sul de MinasEtapa I (COMIG, UFMG, UFRJ, UERJ) (v. 11, 84-119). Belo Horizonte: Companhia Mineradora de Minas Gerais.

Paciullo, F. V. P., Trouw, R. A. J., Ribeiro, A., Simões, L. A., Lopes, M. (2013). Mapa Geológico da Folha Andrelândia. Escala 1:100.000. Belo Horizonte: Companhia de Desenvolvimento Econômico de Minas Gerais.

Pettigrew, N. T., Hattori, K. H. (2006). The Quetico Intrusions of Western Superior Province: Neo-Archean examples of Alaskan/Ural-type mafic-ultramafic intrusions. Precambrian Research, 149, 21-42. https://doi.org/10.1016/j. precamres.2006.06.004

Pinheiro, M. A. P., Suita, M. T. F. (2008). Metamorfismo de fundo oceânico e alto grau em meta-peridotitos ofiolíticos neoproterozóicos, Faixa Brasília Sul, Minas Gerais. Revista Brasileira de Geociências, 38, 686-699.

Pinheiro, M. A. P., Suita, M. T. F. (2011). Aspectos petrográficos e petrológicos de um gnaisse calciossilicático (meta-rodingito) em alto grau na base da Klippe Carvalhos, Faixa Brasília, borda Sul do Cráton São Francisco, em Minas Gerais. Revista Brasileira de Geociencias, 42(3), 489-504. http://dx.doi.org/10.5327/Z0375-75362012000300004

Ribeiro, A., Trouw, R. A. J., Andreis, F. V. P., Paciullo, F. V. P., Valença, J. G. (1995). Evolução das bacias proterozóicas e o termo tectonismo brasiliano na margem sul do cráton do São Francisco. Revista Brasileira de Geociências, 25(4), 235-248.

Ridley, J. (2013). Ore Deposit Geology. Cambridge: Cambridge University Press.

Silva, M. L. M. C., Oliveira, S. M. B. (1995). As fases portadoras de niquel do minerio lateritico do Vermelho, Serra dos Carajas (PA). Revista Brasileira de Geociências, 25(1), 69-78.
Taylor, G., Eggleton, R. A. (2001). Regolith Geology and Geomorphology. Chichester: Wiley.

Thorne, R., Roberts, S., Herrington, R. (2012). The formation and evolution of the Bitincke nickel laterite deposit, Albania. Mineralium Deposita, 47, 933-947. https://doi.org/10.1007/ s00126-012-0411-x

Toledo, M. C. M., Oliveira, S. M. B., Melfi, A. J. (2009). Da rocha ao solo: intemperismo e pedogênese. In: W. Teixeira, M. C. M. Toledo, T. R. Fairchild, F, Taioli. Decifrando a Terra. $2^{\mathrm{a}}$ edição. São Paulo: Companhia Editora Nacional, cap. 8, p. 210-239.

Trescases, J. J., Dino, R., Oliveira, S. M. B. de (1986). Un gisement de nickel supergène en zone semi-aride: São João do Piauí (Brésil). In: R. R. Clemente, Y. Tardy (Eds.), Geochemistry and mineral formation in the earth surface, 237-288. Madri: Proceedings.

Trouw, R. A. J., Ribeiro, A., Paciullo, F. V. P. (1986). Contribuição à geologia de Folha Barbacena, 1:250.000. In: XXXIV Congresso Brasileiro de Geologia, v. 2, 974984. Goiânia: SBG.

Valeton, I. (1972). Bauxites. Developments in Soil Sciences I. Amsterdam: Elsevier.

Villaume, J. F., Rose, A. W. (1977). The geochemistry of some Archean ultramafic lavas. Chemical Geology, 19(14), 43-60. https://doi.org/10.1016/0009-2541(77)90003-1

Wells, M. A., Ramanaidou, E. R., Verrall, M., Tessarolo, C. (2009). Mineralogy and crystal chemistry of "garnierites" in the Goro lateritic nickel deposit, New Caledonia. European Journal of Mineralogy, 21, 467-483. https://doi. org/10.1127/0935-1221/2009/0021-1910

Zozulya, D. R., Savchenko, E. E., Kullerud, K., Ravna, E. K., Lyalina, L. M. (2010). Unique Acessory Ti-Ba-P Mineralization in the Kvalöya Ultrapotassic Dyke, Northern Norway. Geology of Ore Deposits, 52(8), 843-851. https:// doi.org/10.1134/S1075701510080167 